\title{
Penilaian Kualitas Desain Perguruan Tinggi dengan Menggunakan Pendekatan CPTED di Kota Semarang
}

\section{University Design Quality Assessment by Using CPTED Approach in Semarang City}

\author{
Dini Oktaviani Hapsari ${ }^{\mathrm{a}}$, Retno Susanti ${ }^{\mathrm{b}}$ \\ ${ }^{a}$ Departemen Perencanaan Wilayah dan Kota Universitas Diponegoro, Semarang, Indonesia \\ ${ }^{b}$ Departemen Perencanaan Wilayah dan Kota Universitas Diponegoro, Semarang, Indonesia
}

\begin{abstract}
Abstrak
Keberadaan Undip dan Unika di Kota Semarang menjadi daya tarik tersendiri bagi mahasiswa yang berada di luar Kota Semarang. Hal tersebut dapat meningkatkan aktivitas di sekitar kawasan Undip dan Unika. Namun keberadaan dua Perguruan Tinggi tersebut menimbulkan permasalahan baru berupa peningkatan angka kejahatan di sekitar kawasan kampus seperti, pada September 2017, terdapat laporan kehilangan berupa 34 sepeda motor, 133 helm dan 1 spion di kawasan Undip. Sementara itu pada kawasan Unika terdapat kasus pembegalan yang menewaskan seorang laki-laki di dekat gerbang keluar Unika pada tahun 2014. Maka dari itu untuk meminimalisir kasus kejahatan diperlukan adanya pendekatan "Crime Prevention Through Environmental Design (CPTED)" di kawasan kampus sehingga dapat meningkatkan rasa aman bagi mahasiswa pada dua kampus tersebut. Pada penelitian ini, untuk mencapai hasil penilaian kualitas desain, metode analisis yang digunakan adalah metode deskriptif kuantitatif. Teknik analisis yang digunakan adalah Analytical Hierarchy Process (AHP) dan skoring menggunakan kategorial yang disajikan dalam bentuk deskriptif kuantitatif. Hasil penelitian yang diperoleh secara keseluruhan mengenai penilaian kualitas desain, kawasan Undip berada pada kategori cukup dengan sebesar 2,079 dan kawasan Unika berada pada kategori baik dengan skor sebesar 2,378. Perbedaan nilai tersebut dipengaruhi oleh beberapa faktor seperti tata guna lahan, kontur, kepadatan bangunan, luas kawasan, jumlah mahasiswa, dan jumlah aktivitas, yang dapat menyebabkan fasilitas dan kebijakan untuk mengurangi kejahatan dan meningkatkan keamanan di Undip dan Unika berbeda pula.
\end{abstract}

Kata kunci: CPTED, Perguruan Tinggi, Kota Semarang, Kualitas Desain.

\begin{abstract}
The existence of Undip and Unika in Semarang become the main attraction for students who are outside Semarang. It can increase the activity around Undip and Unika areas. Nevertheless, there are some new things happening around the campus area, in September 2017, there were reports of loss of 34 motorcycles, 133 helmets and 1 rearview mirror in Undip. Meanwhile, Unika has a case of murder that killed a man outside the exit gate of Unika in 2014. Therefore to minimize the crime case it is necessary to "Crime Prevention through Environmental Design (CPTED)" in campus area, can improve students' sense of security on the two campuses. In this research, to achieve the result of design quality, the method of analysis used is descriptive quantitative method. Analytical technique used is Analytical Hierarchy Process (AHP) and scoring using categorical given in the form of descriptive quantitative. Results of research that determine in Undip are in the sufficient category with 2,079 and the Unika category is in good category with a score of 2,378 . These differences can be influenced by factors such as land area, contour, building density, area, number of students, and number of activities, which can cause facilities and policies to reduce crime and improve security at Undip and Unika.
\end{abstract}

Keyword: CPTED, University, Semarang City, Design Quality. 


\section{Pendahuluan}

Pada tahun 1971, kriminolog C. Ray Jeffery mencetuskan prinsip Crime Prevention Through Environmental Design (CPTED) untuk meningkatkan keamanan dari kejahatan dan tindakan yang tidak diinginkan dan kemudian dikembangkan beberapa panduan lain untuk membuat suatu daerah menjadi lebih aman dan nyaman (Peeters \& Vander Beken, 2017). CPTED merupakan pendekatan pemecahan masalah dengan mempertimbangkan kondisi lingkungan dan peluang terhadap tindak kejahatan (Zahm, 2007). Perencanaan dengan strategi CPTED ini diharapkan dapat mengurangi tindakan kriminalitas atau mencegah adanya tindakan kejahatan, mengurangi rasa takut, serta kawasan yang menjadi objek desain menjadi lebih aman dan nyaman serta kualitas hidup menjadi meningkat. Upaya dalam mencegah tindak kejahatan dapat dilakukan dengan 4 prinsip CPTED yaitu, Natural Surveillance (Pengawasan Alami), Territorial Reinforcement (Penguatan Batas Wilayah), Access Control (Kontrol Akses), dan Maintenance (Pemeliharaan) yang masing-masing mengatur objek-objek pada kawasan perancangan, khususnya pada kawasan yang rawan tindakan kriminalitas sehingga dapat menciptakan kawasan yang aman dari tindakan kejahatan Jeffery (1971) dalam Sohn (2016).

Secara umum, kejahatan lebih banyak terjadi di kota-kota besar daripada di kota-kota kecil atau daerah pedesaan. Jenis kejahatan yang terjadi di setiap daerah tentu juga berbeda, lokasi yang berada di pusat kota tentu saja memiliki resiko kejahatan yang lebih tinggi (Glaeser \& Sacerdote, 1999). Kejahatan juga banyak terjadi di perkotaan dengan lingkungan sosial yang miskin sehingga mendukung pelaku untuk melakukan kejahatan (Zen, Amalina, \& Mohamad, 2014). Pada kota-kota besar, penyebab tindak kejahatan yang terjadi adalah tingginya tingkat urbanisasi ke kota tersebut. Dalam data statistik kepolisian, tingkat kriminalitas di perkotaan semakin hari semakin meningkat terutama kota-kota besar di Indonesia. Bervariasinya aktivitas yang ada di suatu kota dapat meningkatkan tindak kejahatan di kota tersebut. Kerawanan tindak kejahatan di kota-kota besar dapat dilihat dari beberapa aktivitas yang ada didalamnya seperti di kawasan pendidikan yang dapat memicu tumbuhnya aktivitas-aktivitas pendukung disekitarnya. Pada kawasan pendidikan, yang paling rawan adalah pada kawasan perguruan tinggi. Pada perguruan tinggi kerawanan tindak kejahatan sangat beragam, mulai dari pencurian hingga pembegalan.

Kota Semarang sebagai Ibukota Provinsi Jawa Tengah yang memiliki berbagai perguruan tinggi baik perguruan tinggi negeri maupun swasta menjadikan daya tarik tersendiri bagi para mahasiswa yang berada di luar Kota Semarang. Kota Semarang memiliki 3 Perguruan Tinggi Negeri dan 70 Perguruan Tinggi Swasta (BPS Kota Semarang, 2016) dengan kondisi fisik sekitar kampus yang beragam. Suatu perguruan tinggi seharusnya menempati area yang aman, nyaman dan tenang untuk menuntut ilmu, tetapi Kota Semarang memiliki hal yang berbeda dari kota-kota lain di Indonesia karena beberapa perguruan tinggi di Semarang berada pada daerah yang memiliki kontur curam, berada pada dataran tinggi dan dataran rendah. Akibatnya dapat meningkatkan potensi tindak kejahatan pada lingkungan perguruan tinggi.

Belum terjaminnya keamanan bagi mahasiswa dipengaruhi oleh peningkatan aktivitas di kedua perguruan tinggi tersebut yang menyebabkan angka kejahatan semakin tinggi. Pada tahun 2010, seluruh aktivitas perkuliahan yang berada di kawasan Undip Pleburan dipindahkan ke kawasan Undip Tembalang. Hal tersebut dapat dilihat dari meningkatnya aktivitas dengan ditemukan banyak rumah kos, warung, rumah makan, dan perdagangan jasa lainnya yang berada di sekitar kampus sehingga tindak kejahatan yang terjadi berupa pencurian dan penusukan semakin tinggi. Sementara itu, kampus Unika sejak pertengahan tahun 1990 seluruh aktivitas kampus dipusatkan di kampus Bendan Dhuwur dan hingga saat ini kampus Bendan Dhuwur menjadi pusat kegiatan akademis perguruan tinggi. Meningkatnya perkembangan aktivitas pendukung, sama halnya seperti kampus Undip, pada kampus Unika juga terdapat tindak kejahatan berupa pencurian dan pembegalan.

Permasalahan tindak kejahatan pada kawasan Undip dan Unika dapat dilihat dari beberapa indikator pada pendekatan CPTED yaitu natural surveillance (pengawasan alami), territorial reinforcement (penguatan batas wilayah), access control (kontrol akses), dan maintenance (pemeliharaan). Hasil identifikasi keempat indikator tersebut menjadi dasar analisis penilaian kualitas desain fisik lingkungan di kawasan Undip dan Unika yang memenuhi indikator CPTED. Oleh karena itu perlu dilakukan penelitian mengenai "Berapa nilai kualitas desain kawasan Universitas Diponegoro (Undip) dan Universitas Katolik Soegijapranata 
(Unika) dengan menggunakan pendekatan Crime Prevention Through Environmental Design (CPTED)?"

Pada penanganan kasus tindak kejahatan diperlukan pendekatan CPTED untuk meminimalisir tindak kejahatan, terutama di kawasan fasilitas publik. Salah satu fasilitas publik yang perlu diperhatikan tingkat keamanannya adalah kawasan perguruan tinggi. Kawasan perguruan tinggi memiliki potensi yang tinggi terhadap tindak kejahatan, maka dari itu CPTED di perguruan tinggi sangat diperlukan untuk mengurangi tingkat kejahatan di kawasan tersebut. Hal tersebut juga berlaku pada kawasan perguruan tinggi di Kota Semarang. Namun, kenyataannya perguruan tinggi di Kota Semarang masih belum menerapkan CPTED dalam mengurangi tingkat kejahatan. Walaupun ada yang menerapkan CPTED, masih belum maksimal dalam pelaksanaannya. Maka dari itu diperlukan suatu penanganan tindak kejahatan melalui penerapan CPTED.

\section{Metode}

Pada penelitian ini terdapat 2 identifikasi untuk menentukan nilai kualitas desain fisik kawasan Perguruan Tinggi di Kota Semarang, yaitu identifikasi karakteristik aktivitas mahasiswa, dan identifikasi kondisi perguruan tinggi berdasarkan pendekatan CPTED. Berdasarkan hasil kedua identifikasi tersebut, dilakukan penentuan bobot indikator pada setiap variabel dengan menggunakan Analytical Hierarchy Process (AHP) yang ditujukan kepada 3 pakar akademisi pada bidang arsitektur, maka akan menghasilkan penilaian kualitas desain berdasarkan pendekatan CPTED sesuai dengan hasil pembobotan dan skor pada setiap indikator dan variabel.

Pada penelitian ini, untuk menentukan sampel menggunakan nonprobability sampling yaitu aksidental sampling untuk pengumpulan data kuesioner bagi mahasiswa. Pada penelitian ini juga menggunakan purposif sampling untuk mengumpulkan data wawancara yang ditujukan kepada pihak penjaga kampus di setiap universitas. Adapun jumlah sampel mahasiswa yang digunakan, berdasarkan Rumus Slovin dan derajat kecermatan yang digunakan adalah $10 \%$ sehingga untuk tingkat kecermatan sebesar $90 \%$ yang menunjukkan tingkat kecermatan studi berada pada kategori cermat. Berikut Rumus Slovin yang digunakan:

$$
n=\frac{N}{N d^{2}+1}
$$

- Universitas Diponegoro

- Universitas Katolik Soegijapranata

$$
\begin{aligned}
& n=\frac{39.961}{\left(39.961 \times 0,1^{2}\right)+1} \\
& n=99,75 \approx 100
\end{aligned}
$$

$$
\begin{aligned}
& n=\frac{7.067}{\left(7.067 \times 0,1^{2}\right)+1} \\
& n=98,60 \approx 100
\end{aligned}
$$

Pada setiap sampel yang digunakan, untuk distribusi responden pada setiap perguruan tinggi dilakukan perbandingan proporsional dengan jumlah mahasiswa aktif disetiap fakultas. Saat menentukan kelas atau kategori pada identifikasi karakteristik aktivitas dan kondisi perguruan tinggi dengan menggunakan pendekatan CPTED, diperlukan perhitungan dengan menggunakan Rumus Sturgess yaitu sebagai berikut:

$$
\begin{aligned}
& K=1+3,3 \log n \\
& K=1+3,3 \log 4 \\
& K=1+3,3(0,6) \\
& K=1+1,98 \\
& K=2,98 \approx 3
\end{aligned}
$$

Pada tiga kategori tersebut, kemudian dibagi kedalam kategori kurang, cukup dan baik. Kemudian untuk menentukan bobot setiap indikator dalam variabel menggunakan rumus perhitungan AHP yang menghasilkan besaran bobot setiap variabel dan indikator. Besaran bobot tersebut kemudian digunakan untuk melakukan analisis pembobotan dan skoring, yang kemudian berdasarkan hasil skor didapat tiga kelas atau kategori penilaian kualitas desain kawasan perguruan tinggi yaitu 


$\begin{array}{lll}- & \text { Kurang } & =1-1,67 \\ \text { - } & \text { Cukup } & =1,68-2,35 \\ \text { - } & \text { Baik } & =2,36-3,03\end{array}$

\section{Kajian Literatur Pencegahan Tindak Kejahatan dan Pendekatan CPTED dalam Penilaian Kualitas Desain Kawasan Perguruan Tinggi}

Perguruan tinggi merupakan ruang yang bersifat publik karena dapat diakses oleh mahasiswa dari berbagai kalangan yang dapat membentuk karakteristik mahasiswa. Karakteristik tersebut telah membentuk pola yang dilakukan oleh mahasiswa secara berulang. Berikut karakteristik aktivitas mahasiswa adalah waktu mahasiswa mendatangi lingkungan kampus, intensitas waktu mahasiswa mendatangi lingkungan kampus, tujuan mahasiswa mendatangi lingkungan kampus, dan moda transportasi yang digunakan mahasiswa (Rizkyawan, 2012).

Definisi mengenai tindak kejahatan banyak didefinisikan oleh para peneliti. Pada subbab ini menjelaskan mengenai pengertian tindak kejahatan yang dikemukakan oleh beberapa ahli. Pengertian tindak kejahatan yang pertama adalah menurut B. Simanjuntak dalam Supandi (2015), tindak kejahatan didefinisikan sebagai tindakan anti sosial yang merugikan yang dapat menimbulkan kegoncangan dalam masyarakat. Kemudian yang kedua dikemukakan oleh Van Bammelen dalam Supandi (2015), tindak kejahatan adalah perilaku yang tidak susila dan merugikan, serta menimbulkan ketidaktenangan masyarakat dan yang terakhir atau ketiga dikemukakan oleh J.M. Bemmelem dalam Supandi (2015), tindak kejahatan adalah tindakan anti sosial yang menimbulkan kerugian sehingga masyarakat menjadi gelisah, dan untuk menentramkannya, negara harus menjatuhkan hukuman kepada pelaku kejahatan.

Untuk pendekatan CPTED yang pertama bermula pada tahun 1961, Jane Jacobs menemukan adanya hubungan antara keamanan, konsep mixed-use, kawasan yang ramai, desain ruang kota, dengan kemungkinan-kemungkinan dari penduduk perkotaan. 10 tahun kemudian muncullah prinsip Crime Prevention through Environmental Design (CPTED) yang didefinisikan sebagai sebuah teknik untuk mengurangi atau menghilangkan rasa takut dan kejahatan dengan mengedepankan konsep pengawasan oleh lingkungan dan peran komunitas masyarakat (Clarke, 2009). Dr C. Ray Jeffery, yang tertarik dengan CPTED yang dicetuskan oleh Jane Jacobs, melakukan pendekatan interdisipliner untuk pencegahan kejahatan yang berfokus pada perubahan perilaku pelaku dengan mengubah lingkungan pelaku.

Pada tahun 1972, arsitek Oscar Newman mempublikasikan konsep Defensible Space yaitu Crime Prevention through Urban Design atau dikenal dengan Pencegahan Kejahatan Melalui Desain Perkotaan. Newman bekerja di perumahan publik untuk menentukan bagaimana desain dan karakteristik sosial berkorespondensi dengan lingkungan yang aman dan produktif. Penelitian oleh Oscar Newman didasarkan pada perencanaan kota dan arsitektur desain, dengan penekanan pada kriminologi dan ilmu perilaku. Hasil konsep tersebut kemudian menjadi dasar dari prinsip CPTED.

Secara mendasar, Sohn (2016) dan Singapore National Crime Prevention Council (2003) mengemukakan bahwa dalam pendekatan Crime Prevention Through Environmental Design (CPTED) terdapat empat prinsip pendekatan yang diterapkan.yaitu:

\section{Natural Surveillance / Pengawasan Alami}

Pengawasan alami merupakan desain pada kawasan yang menempatkan desain fisik untuk mencegah kejahatan pada sarana dan prasarana dengan upaya memaksimalkan kemampuan untuk mengawasi suatu ruang (Danville Police, 2012). Prinsip ini dapat dilakukan dengan beberapa teknik seperti, menempatkan bangunan dengan menghadap ke jalan, memiliki penerangan yang memadai sesuai dengan standar, desain bangunan sebaiknya tidak memicu munculnya tempat persembunyian bagi pelaku kejahatan, dan memiliki rute jalan terlihat dari segala arah. Strategi ini cukup efektif dilakukan karena pelaku kejahatan tidak akan melakukan kejahatan di daerah yang mereka merasakan jika diamati. Jika terjadi kejahatan kemungkinan besar akan diketahui oleh orang lain dan dapat dilaporkan ke pihak yang berwenang (Danville Police, 2012).

2. Territorial Reinforcement / Penguatan Batas Wilayah

Penguatan batas wilayah digunakan untuk memberikan batas yang jelas antara kawasan publik dan kawasan pribadi dengan menggunakan unsur fisik seperti pagar, perkerasan trotoar, 
rambu penunjuk jalan dan pemeliharaan yang baik untuk menunjukan kepemilikan wilayah (Pauls et al., 2000). Mengidentifikasi pelaku kejahatan dapat lebih muda dilakukan pada ruang yang telah diketahui kepemilikannya. Penguatan batas wilayah dapat dilaksanakan jika suatu ruang memiliki kepemilikan yang jelas sehingga menghambat pelaku kejahatan untuk melakukan aksinya. Strategi ini dapat dilakukan karena dapat menunjukkan apakah ada orang asing yang memasuki kawasan sehingga bagi siapapun yang berada pada kawasan tersebut dapat mengawasi apabila terdapat tindak kejahatan (Danville Police, 2012).

3. Access Control / Kontrol Akses

Kontrol akses yang dilakukan berupa kontrol akses secara alami dengan memperhatikan keberadaan pintu, pagar, semak, portal, dan elemen-elemen fisik lainnya yang membatasi seseorang yang tidak berwenang untuk memasuki suatu wilayah. Selain itu juga untuk menciptakan persepsi bagi pelaku kejahatan bahwa terdapat resiko ketika memilih target kejahatan (Pauls et al., 2000). Prinsip ini dapat tercipta melalui desain jalan, pedestrian way, pintu masuk utama dan pintu samping bangunan yang secara jelas dapat mengindikasikan perbedaan kawasan publik dan privat serta jalur-jalur yang dapat/boleh dilewati oleh umum, dan mampu mengurangi rasa bebas pengguna ketika memasuki kawasan privat (Wizaka, 2012). Strategi terhadap pengawasan terhadap akses dilakukan untuk menciptakan penghalang terhadap orang/kendaraan asing yang memasuki suatu kawasan (Danville Police, 2012).

4. Maintenance / Pemeliharaan

Pemeliharaan perlu diperhatikan pada tahap perancangan seperti pemilihan desain bangunan yang berpengaruh terhadap jenis pemeliharaan fisik bangunan yang dilakukan sehingga bangunan yang ada dapat dilestarikan dari waktu ke waktu. Prinsip ini ditujukan untuk menciptakan hambatan pada setiap jalur masuk seperti jendela, pintu masuk dan pintu-pintu di dalam bangunan (Wizaka, 2012). Strategi ini bertujuan untuk mencapai penggunaan ruang secara terus menerus dengan tujuan yang telah ditentukan dan merupakan tanggung jawab bagi pemilik, operator dan penghuni bangunan (Pauls et al., 2000).

\section{Analisis Penilaian Kualitas Desain Perguruan Tinggi dengan Menggunakan Pendekatan CPTED di Kota Semarang}

Penilaian kualitas desain kawasan Undip dan Unika berdasarkan persepsi mahasiswa dilihat melalui karakteristik aktivitas mahasiswa dan kondisi perguruan tinggi menggunakan pendekatan CPTED. Penentuan skor dilakukan berdasarkan indikator dan klasifikasi penilaian yang telah dibuat sebelumnya. Pada penilaian ini terdapat 3 klasifikasi dalam pemberian nilai, nilai 1 merupakan nilai terendah dan nilai 3 merupakan nilai tertinggi. Kemudian jumlah pada setiap penilaian dikalikan dengan nilai dan setiap total nilai tersebut dijumlah, kemudian dibagi dengan 100 yang merupakan jumlah responden dan akan menghasilkan total nilai akhir. Berikut merupakan hasil pemberian nilai pada setiap perguruan tinggi berdasarkan hasil kuesioner yang ditujukan kepada mahasiswa Undip dan Unika.

Tabel 1. Nilai Indikator Kualitas Desain Kawasan Undip (Analisis Penyusun, 2018)

\begin{tabular}{|c|c|c|c|c|c|c|c|c|c|c|c|c|c|}
\hline \multirow[b]{2}{*}{ Variabel } & \multirow[b]{2}{*}{ Indikator } & \multicolumn{3}{|c|}{ Kurang } & \multicolumn{3}{|c|}{ Cukup } & \multicolumn{3}{|c|}{ Baik } & \multirow{2}{*}{$\begin{array}{c}\text { Total } \\
\text { Nilai } \\
\text { (T1+T2+ } \\
\text { T3) }\end{array}$} & \multirow{2}{*}{$\begin{array}{c}\text { Total } \\
\text { Nilai } \\
\text { Akhir } \\
\text { (N) }\end{array}$} & \multirow[b]{2}{*}{ Kategor } \\
\hline & & $\underset{(\mathbf{r})}{\operatorname{Jumlah}}$ & $\begin{array}{c}\text { Nilai } \\
(\mathbf{n})\end{array}$ & $\begin{array}{l}\text { Total } \\
\text { (T1= } \\
\text { rxn) }\end{array}$ & $\underset{(\mathbf{r})}{\text { Jumlah }}$ & $\begin{array}{c}\text { Nilai } \\
(n)\end{array}$ & $\begin{array}{l}\text { Total } \\
\text { (T2= } \\
\text { rxn) }\end{array}$ & $\underset{(\mathbf{r})}{\operatorname{Jumlah}}$ & $\begin{array}{c}\text { Nilai } \\
(\mathbf{n})\end{array}$ & $\begin{array}{l}\text { Total } \\
\text { (T3= } \\
\text { rxn) }\end{array}$ & & & \\
\hline \multirow{4}{*}{$\begin{array}{c}\text { Karakteristik } \\
\text { Aktivitas } \\
\text { Mahasiswa }\end{array}$} & $\begin{array}{l}\text { Waktu Mendatangi Lingkun } \\
\text { Kampus }\end{array}$ & & & & & & & & & & & 2 & Cukup \\
\hline & $\begin{array}{l}\text { Intensitas Waktu Mendatang } \\
\text { Lingkungan Kampus }\end{array}$ & & & & & & & & & & & 2 & Cukup \\
\hline & Tujuan ke Kampus & & & & & & & & & & & 2 & Cukup \\
\hline & Moda Transportasi & & & & & & & & & & & 2 & Cukup \\
\hline & Pos Satpam & 44 & 1 & 44 & 26 & 2 & 52 & 30 & 3 & 90 & 186 & 1.86 & Cukup \\
\hline & Lampu Penerangan & 30 & 1 & 30 & 49 & 2 & 98 & 21 & 3 & 63 & 191 & 1.91 & Cukup \\
\hline Surveillance & $\begin{array}{l}\text { Bangunan yang Mudah } \\
\text { Diamati }\end{array}$ & 8 & 1 & 8 & 44 & 2 & 88 & 48 & 3 & 144 & 240 & 2.4 & Baik \\
\hline 产 & $\begin{array}{l}\text { Pengaturan Tinggi Pohon } \\
\text { dan Semak }\end{array}$ & 33 & 1 & 33 & 44 & 2 & 88 & 23 & 3 & 69 & 190 & 1.9 & Cukup \\
\hline \multirow{3}{*}{$\begin{array}{c}\text { Territorial } \\
\text { Reinforcement }\end{array}$} & Pagar/ Portal/ Semak & 28 & 1 & 28 & 51 & 2 & 102 & 21 & 3 & 63 & 193 & 1.93 & Cukup \\
\hline & $\begin{array}{l}\text { Penanda Jurusan/ } \\
\text { Fakultas/ Universitas }\end{array}$ & 7 & 1 & 7 & 41 & 2 & 82 & 52 & 3 & 156 & 245 & 2.45 & Baik \\
\hline & Trotoar & 20 & 1 & 20 & 47 & 2 & 94 & 33 & 3 & 99 & 213 & 2.13 & Cukup \\
\hline
\end{tabular}




\begin{tabular}{|c|c|c|c|c|c|c|c|c|c|c|c|c|c|}
\hline \multirow[b]{2}{*}{ Variabel } & \multirow[b]{2}{*}{ Indikator } & \multicolumn{3}{|c|}{ Kurang } & \multicolumn{3}{|c|}{ Cukup } & \multicolumn{3}{|c|}{ Baik } & \multirow{2}{*}{$\begin{array}{c}\text { Total } \\
\text { Nilai } \\
\text { (T1+T2+ } \\
\text { T3) }\end{array}$} & \multirow{2}{*}{$\begin{array}{c}\text { Total } \\
\text { Nilai } \\
\text { Akhir } \\
\text { (N) }\end{array}$} & \multirow[b]{2}{*}{ Kategori } \\
\hline & & $\begin{array}{c}\text { Jumlah } \\
\text { (r) }\end{array}$ & $\underset{(\mathbf{n})}{\text { Nilai }}$ & $\begin{array}{l}\text { Total } \\
(\text { T1= } \\
\text { rxn) }\end{array}$ & $\begin{array}{c}\text { Jumlah } \\
\text { (r) }\end{array}$ & $\begin{array}{c}\text { Nilai } \\
(\mathbf{n})\end{array}$ & $\begin{array}{l}\text { Total } \\
(\mathrm{T} 2= \\
\text { rxn })\end{array}$ & $\begin{array}{c}\text { Jumlah } \\
\text { (r) }\end{array}$ & $\underset{(\mathbf{n})}{\text { Nilai }}$ & $\begin{array}{l}\text { Total } \\
(\mathrm{T3}= \\
\text { rxn })\end{array}$ & & & \\
\hline \multirow{4}{*}{$\begin{array}{l}\text { Access } \\
\text { Control }\end{array}$} & $\begin{array}{l}\text { Pintu Masuk Kawasan } \\
\text { Perguruan Tinggi }\end{array}$ & 13 & 1 & 13 & 37 & 2 & 74 & 50 & 3 & 150 & 237 & 2.37 & Baik \\
\hline & Pagar/ Portal/ Semak & 28 & 1 & 28 & 51 & 2 & 102 & 21 & 3 & 63 & 193 & 1.93 & Cukup \\
\hline & CCTV & 30 & 1 & 30 & 62 & 2 & 124 & 8 & 3 & 24 & 178 & 1.78 & Cukup \\
\hline & Pos Satpam & 44 & 1 & 44 & 26 & 2 & 52 & 30 & 3 & 90 & 186 & 1.86 & Cukup \\
\hline \multirow{4}{*}{ Maintenance } & Pemeliharaan Penanda & & & & & & & & & & & 3 & Baik \\
\hline & $\begin{array}{l}\text { Pemeliharaan Fasilitas } \\
\text { Keamanan }\end{array}$ & & & & & & & & & & & 2 & Cukup \\
\hline & $\begin{array}{l}\text { Pemotongan Tumbuhan } \\
\text { Sudah Lebat }\end{array}$ & & & & & & & & & & & 2 & Cukup \\
\hline & Standar Keamanan Pint & suk & & & & & & & & & & 2 & Cukup \\
\hline \multicolumn{2}{|c|}{ Rata-rata } & 25.91 & & & 43.45 & & & 30.64 & & & 100 & 39.52 & \\
\hline
\end{tabular}

Tabel 2. Nilai Indikator Kualitas Desain Kawasan Unika (Analisis Penyusun, 2018)

\begin{tabular}{|c|c|c|c|c|c|c|c|c|c|c|c|c|c|c|}
\hline \multirow{2}{*}{\multicolumn{2}{|c|}{ Variabel }} & \multirow[b]{2}{*}{ Indikator } & \multicolumn{3}{|c|}{ Kurang } & \multicolumn{3}{|c|}{ Cukup } & \multicolumn{3}{|c|}{ Baik } & \multirow{2}{*}{$\begin{array}{c}\text { Total } \\
\text { Nilai } \\
\text { (T1+T2+ } \\
\text { T3) }\end{array}$} & \multirow{2}{*}{$\begin{array}{l}\text { Total } \\
\text { Nilai } \\
\text { Akhir } \\
\text { (N) }\end{array}$} & \multirow[b]{2}{*}{ Kategori } \\
\hline & & & $\underset{(\mathbf{r})}{\text { Jumlah }}$ & $\begin{array}{l}\text { Nilai } \\
\text { (n) }\end{array}$ & $\begin{array}{l}\text { Total } \\
\text { (T1= } \\
\text { rxn) }\end{array}$ & $\begin{array}{c}\text { Jumlah } \\
\text { (r) }\end{array}$ & $\begin{array}{c}\text { Nilai } \\
(\mathbf{n})\end{array}$ & $\begin{array}{l}\text { Total } \\
\text { (T2= } \\
\text { rxn) }\end{array}$ & $\underset{\text { (r) }}{\text { Jumlah }}$ & $\underset{(\mathbf{n})}{\text { Nilai }}$ & $\begin{array}{l}\text { Total } \\
\text { (T3= } \\
\text { rxn) }\end{array}$ & & & \\
\hline \multirow{4}{*}{\multicolumn{2}{|c|}{$\begin{array}{c}\text { Karakteristik } \\
\text { Aktivitas } \\
\text { Mahasiswa }\end{array}$}} & $\begin{array}{l}\text { Waktu Mendatangi Lingkungan } \\
\text { Kampus }\end{array}$ & & & & & & & & & & & 2 & Cukup \\
\hline & & $\begin{array}{l}\text { Intensitas Waktu Mendatangi } \\
\text { Lingkungan Kampus }\end{array}$ & & & & & & & & & & & 2 & Cukup \\
\hline & & Tujuan ke Kampus & & & & & & & & & & & 2 & Cukup \\
\hline & & Moda Transportasi & & & & & & & & & & & 2 & Cukup \\
\hline \multirow{15}{*}{ 논 } & & Pos Satpam & 0 & 1 & 0 & 6 & 2 & 12 & 94 & 3 & 282 & 294 & 2.94 & Baik \\
\hline & & Lampu Penerangan & 23 & 1 & 23 & 38 & 2 & 76 & 39 & 3 & 117 & 216 & 2.16 & Cukup \\
\hline & $\begin{array}{c}\text { Natural } \\
\text { Surveillance }\end{array}$ & $\begin{array}{l}\text { Bangunan yang Mudah } \\
\text { Diamati }\end{array}$ & 2 & 1 & 2 & 39 & 2 & 78 & 59 & 3 & 177 & 257 & 2.57 & Baik \\
\hline & & $\begin{array}{l}\text { Pengaturan Tinggi Pohon } \\
\text { dan Semak }\end{array}$ & 17 & 1 & 17 & 30 & 2 & 60 & 53 & 3 & 159 & 236 & 2.36 & Baik \\
\hline & & Pagar/ Portal/ Semak & 7 & 1 & 7 & 31 & 2 & 62 & 62 & 3 & 186 & 255 & 2.55 & Baik \\
\hline & $\begin{array}{c}\text { Territorial } \\
\text { Reinforcement }\end{array}$ & $\begin{array}{l}\text { Penanda Jurusan/ Fakultas/ } \\
\text { Universitas }\end{array}$ & 22 & 1 & 22 & 51 & 2 & 102 & 27 & 3 & 81 & 205 & 2.05 & Baik \\
\hline & & Trotoar & 28 & 1 & 28 & 46 & 2 & 92 & 26 & 3 & 78 & 198 & 1.98 & Cukup \\
\hline & \multirow{4}{*}{$\begin{array}{l}\text { Access } \\
\text { Control }\end{array}$} & $\begin{array}{l}\text { Pintu Masuk Kawasan } \\
\text { Perguruan Tinggi }\end{array}$ & 9 & 1 & 9 & 16 & 2 & 32 & 75 & 3 & 225 & 266 & 2.66 & Baik \\
\hline & & Pagar/ Portal/ Semak & 7 & 1 & 7 & 31 & 2 & 62 & 62 & 3 & 186 & 255 & 2.55 & Baik \\
\hline & & CCTV & 11 & 1 & 11 & 61 & 2 & 122 & 28 & 3 & 84 & 217 & 2.17 & Cukup \\
\hline & & Pos Satpam & 0 & 1 & 0 & 6 & 2 & 12 & 94 & 3 & 282 & 294 & 2.94 & Baik \\
\hline & \multirow{4}{*}{ Maintenance } & Pemeliharaan Penanda & & & & & & & & & & & 3 & Baik \\
\hline & & $\begin{array}{l}\text { Pemeliharaan Fasilitas } \\
\text { Keamanan }\end{array}$ & & & & & & & & & & & 3 & Baik \\
\hline & & $\begin{array}{l}\text { Pemotongan Tumbuhan yang } \\
\text { Sudah Lebat }\end{array}$ & & & & & & & & & & & 2 & Cukup \\
\hline & & Standar Keamanan Pintu Masuk & & & & & & & & & & & 3 & Baik \\
\hline \multicolumn{3}{|c|}{ Rata-rata } & 11.45 & & & 32.27 & & & 56.27 & & & 100 & 45.93 & \\
\hline
\end{tabular}

Pada penelitian ini, terdapat 2 variabel yang digunakan yaitu karakteristik aktivitas mahasiswa dan kondisi perguruan tinggi menggunakan pendekatan CPTED. Masing-masing variabel tersebut perlu diketahui bobotnya dengan menggunakan metode AHP. AHP dilakukan dengan membandingkan tingkat kepentingan setiap variabel melalui pengisian kuesioner yang ditujukan kepada 4 pakar yaitu akademisi pada bidang arsitektur. Ketiga akademisi tersebut memberikan penilaian berdasarkan tingkat kepentingan dengan nilai paling tinggi adalah 5 yaitu lebih penting. Perhitungan yang dilakukan memiliki nilai Consistency Ratio (CR) tidak boleh lebih dari 0,100 supaya hasilnya dapat dikatakan konsisten. Penentuan bobot berdasarkan kuesioner pada akademisi arsitektur yaitu 2 Dosen Arsitektur Undip dan Unika. Berikut hasil akhir perhitungan bobot pada variabel penelitian. 
Tabel 3. Hasil Akhir Perhitungan Bobot Variabel (Analisis Penyusun, 2018)

\begin{tabular}{ccc}
\hline No. & Variabel & Bobot \\
\hline $\mathbf{1}$ & Aktivitas Mahasiswa & 0.240 \\
\hline $\mathbf{2}$ & Pendekatan CPTED & 0.760 \\
\hline & Total & $\mathbf{1}$ \\
\hline & Consistency Ratio (CR) & $\mathbf{0}$ \\
\hline
\end{tabular}

Tabel 4. Hasil Akhir Perhitungan Bobot Variabel CPTED (Analisis Penyusun, 2018)

\begin{tabular}{ccc}
\hline No. & Variabel & Bobot \\
\hline $\mathbf{1}$ & Natural Surveillance & 0.256 \\
\hline $\mathbf{2}$ & Territorial Reinforcement & 0.293 \\
\hline $\mathbf{3}$ & Access Control & 0.219 \\
\hline $\mathbf{4}$ & Maintenance & 0.232 \\
\hline & Total & $\mathbf{1}$ \\
\hline & Consistency Ratio (CR) & $\mathbf{0 . 0 6 2}$ \\
\hline
\end{tabular}

Pada perhitungan bobot tersebut diketahui bahwa bobot variabel pendekatan CPTED $(0,760)$ merupakan variabel yang perlu diperhatikan dan dipertimbangkan dalam meningkatkan keamanan di perguruan tinggi. Pada bobot variabel CPTED, Territorial Reinforcement $(0,293)$ dan Natural Surveillance $(0,256)$ merupakan variabel penting yang perlu diperhatikan jika dibandingkan Maintenance $(0,232)$ dan Access Control $(0,219)$, dalam hal untuk meningkatkan keamanan di perguruan tinggi.

Penentuan bobot dilakukan dengan cara membandingkan tingkat kepentingan setiap indikator pada setiap variabel melalui pengisian kuesioner yang sama kepada 4 akademisi. Hasil kuesioner ketiga akademisi tersebut memberikan hasil perhitungan yang berbeda-beda dengan total bobot pada setiap variabel adalah 1 dengan nilain Consistency Ratio (CR) tidak lebih dari 0,100. Berikut hasil akhir perhitungan bobot indikator.

Tabel 5. Hasil Akhir Perhitungan Bobot Indikator Karakteristik Aktivitas Mahasiswa (Analisis Penyusun, 2018)

\begin{tabular}{|c|c|c|c|c|}
\hline Variabel & $\begin{array}{c}\text { Bobot } \\
\text { Variabel } \\
\text { (V) }\end{array}$ & Indikator & $\begin{array}{c}\text { Bobot } \\
\text { Indikator } \\
\text { (I) }\end{array}$ & $\begin{array}{c}\text { Bobot Akhir (V } \\
\text { x I) }\end{array}$ \\
\hline \multirow{5}{*}{$\begin{array}{c}\text { Karakteristik } \\
\text { Aktivitas } \\
\text { Mahasiswa }\end{array}$} & \multirow[t]{5}{*}{0.240} & Waktu Mendatangi Lingkungan Kampus & 0.350 & 0.084 \\
\hline & & Intensitas Waktu Mendatangi Lingkungan Kampus & 0.235 & 0.056 \\
\hline & & Tujuan ke Kampus & 0.245 & 0.059 \\
\hline & & Moda Transportasi & 0.170 & 0.041 \\
\hline & & $\begin{array}{l}\text { Total Bobot Variabel Karakteristik Aktivitas } \\
\text { Mahasiswa }\end{array}$ & 1 & 0.240 \\
\hline
\end{tabular}

Tabel 6. Hasil Akhir Perhitungan Bobot Indikator CPTED (Analisis Penyusun, 2018)

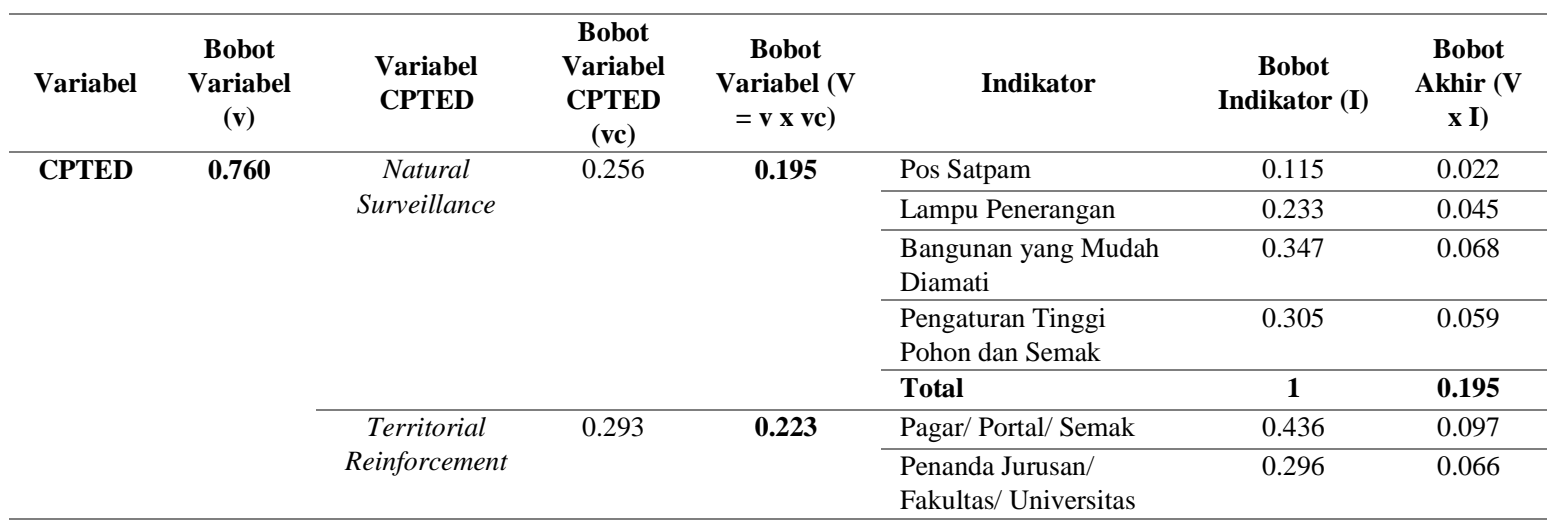




\begin{tabular}{|c|c|c|c|c|c|c|c|}
\hline Variabel & $\begin{array}{c}\text { Bobot } \\
\text { Variabel } \\
(\mathbf{v})\end{array}$ & $\begin{array}{l}\text { Variabel } \\
\text { CPTED }\end{array}$ & $\begin{array}{c}\text { Bobot } \\
\text { Variabel } \\
\text { CPTED } \\
\text { (vc) }\end{array}$ & $\begin{array}{c}\text { Bobot } \\
\text { Variabel (V } \\
=\mathbf{v} \times \mathbf{v c})\end{array}$ & Indikator & $\begin{array}{c}\text { Bobot } \\
\text { Indikator (I) }\end{array}$ & $\begin{array}{c}\text { Bobot } \\
\text { Akhir (V } \\
\text { x I) }\end{array}$ \\
\hline & & & & & Trotoar & 0.268 & 0.060 \\
\hline & & & & & Total & 1 & 0.223 \\
\hline & & \multirow[t]{5}{*}{ Access Control } & \multirow[t]{5}{*}{0.219} & \multirow[t]{5}{*}{0.166} & $\begin{array}{l}\text { Pintu Masuk Kawasan } \\
\text { Perguruan Tinggi }\end{array}$ & 0.246 & 0.041 \\
\hline & & & & & Pagar/ Portal/ Semak & 0.214 & 0.036 \\
\hline & & & & & CCTV & 0.238 & 0.040 \\
\hline & & & & & Pos Satpam & 0.302 & 0.050 \\
\hline & & & & & Total & 1 & 0.166 \\
\hline & & \multirow[t]{5}{*}{ Maintenance } & \multirow[t]{5}{*}{0.238} & \multirow[t]{5}{*}{0.176} & Pemeliharaan Penanda & 0.211 & 0.037 \\
\hline & & & & & $\begin{array}{l}\text { Pemeliharaan Fasilitas } \\
\text { Keamanan }\end{array}$ & 0.244 & 0.043 \\
\hline & & & & & $\begin{array}{l}\text { Pemotongan Tumbuhan } \\
\text { yang Sudah Lebat }\end{array}$ & 0.244 & 0.043 \\
\hline & & & & & $\begin{array}{l}\text { Standar Keamanan Pintu } \\
\text { Masuk }\end{array}$ & 0.300 & 0.053 \\
\hline & & & & & Total & 1 & 0.176 \\
\hline \multicolumn{6}{|c|}{ Total Bobot Variabel CPTED } & & 0.760 \\
\hline \multicolumn{7}{|c|}{ Total Bobot Variabel Karakteristik Aktivitas Mahasiswa dan CPTED } & 1 \\
\hline
\end{tabular}

Berdasarkan hasil akhir perhitungan bobot indikator, besaran bobot indikator (I) menunjukkan tingkat kepentingan indikator tersebut sesuai dengan variabelnya masing-masing. Pada variabel karakteristik aktivitas mahasiswa memiliki bobot sebesar 0,240 dan untuk variabel CPTED memiliki bobot sebesar 0,760. Bobot indikator tertinggi pada variabel karakteristik aktivitas mahasiswa adalah waktu mendatangi lingkungan kampus dengan bobot indikator sebesar 0,350. Hal tersebut karena karakteristik aktivitas sangat memperhatikan waktu datang ke lingkungan kampus, semakin banyak mahasiswa yang mendatangi kampus pada waktu tertentu, maka akan meningkatkan aktivitas yang ada di perguruan tinggi. Sementara itu, untuk bobot indikator terendah pada variabel karakteristik aktivitas mahasiswa adalah moda transportasi dengan bobot indikator sebesar 0,170. Hal tersebut karena moda transportasi kurang penting jika dibandingkan dengan indikator lain pada variabel karakteristik aktivitas mahasiswa.

Dua bobot tertinggi pada variabel CPTED adalah Territorial Reinforcement dengan bobot sebesar 0,223 dan Natural Surveillance dengan bobot sebesar 0,195. Pada Territorial Reinforcement bobot yang paling tinggi adalah pagar/portal/semak dengan bobot sebesar 0,436, maka dapat diartikan bahwa keberadaan pagar/portal/semak merupakan hal yang penting dalam mengurangi tingkat kejahatan. Sementara itu, untuk Natural Surveillance memiliki bobot yang paling tinggi yaitu bangunan yang mudah diamati dengan bobot sebesar 0,347, artinya bahwa kemudahan mahasiswa dalam mengamati bangunan baik dari dalam maupun luar bangunan dapat mengurangi niat pelaku untuk melakukan kejahatan.

Besaran bobot akhir didapat setelah menjumlahkan bobot indikator dengan hasil akhir 1 . Bobot akhir tersebut kemudian digunakan untuk analisis selanjutnya yaitu penilaian kualitas desain kawasan perguruan tinggi dengan menggunakan analisis pembobotan dan skor. Selanjutnya, bobot akhir dapat menunjukkan tingkat kepentingan untuk melakukan peningkatan kualitas desain kawasan menggunakan pendekatan CPTED. Semakin tinggi bobot yang dimiliki, maka indikator tersebut merupakan indikator yang penting dalam peningkatan kualitas desain menggunakan pendekatan CPTED. Namun, jika semakin rendah bobot yang dimiliki, maka indikator tersebut merupakan indikator yang tidak begitu penting dalam peningkatan kualitas desain menggunakan pendekatan CPTED.

Penilaian kualitas desain kawasan Undip dan Unika dapat diketahui dari total nilai yang didapatkan. Penilaian tersebut dilakukan dengan cara mengkalikan bobot dengan nilai setiap indikator. Perhitungan pembobotan dan skoring untuk mengetahui penilaian kualitas desain kawasan Undip dan Unika dapat dilihat pada tabel berikut. 
Tabel 7. Pembobotan dan Skoring Penilaian Kualitas Desain Kawasan Undip (Analisis Penyusun, 2018)

\begin{tabular}{|c|c|c|c|c|c|}
\hline \multicolumn{2}{|c|}{ Variabel } & Indikator & $\begin{array}{l}\text { Bobot } \\
\text { (B) }\end{array}$ & $\begin{array}{l}\text { Nilai } \\
(\mathbf{N})\end{array}$ & $\begin{array}{l}\text { Total Skor } \\
(\text { (B x N) }\end{array}$ \\
\hline \multirow{4}{*}{\multicolumn{2}{|c|}{$\begin{array}{c}\text { Karakteristik Aktivitas } \\
\text { Mahasiswa }\end{array}$}} & Waktu Mendatangi Lingkungan Kampus & 0.092 & 2 & 0.168 \\
\hline & & $\begin{array}{l}\text { Intensitas Waktu Mendatangi Lingkungan } \\
\text { Kampus }\end{array}$ & 0.065 & 2 & 0.113 \\
\hline & & Tujuan ke Kampus & 0.074 & 2 & 0.117 \\
\hline & & Moda Transportasi & 0.047 & 2 & 0.081 \\
\hline \multirow[t]{16}{*}{ CPTED } & \multirow{4}{*}{$\begin{array}{c}\text { Natural } \\
\text { Surveillance }\end{array}$} & Pos Satpam & 0.022 & 1.86 & 0.042 \\
\hline & & Lampu Penerangan & 0.045 & 1.91 & 0.087 \\
\hline & & Bangunan yang Mudah Diamati & 0.067 & 2.4 & 0.162 \\
\hline & & Pengaturan Tinggi Pohon dan Semak & 0.059 & 1.9 & 0.113 \\
\hline & \multirow{3}{*}{$\begin{array}{l}\text { Territorial } \\
\text { Reinforcement }\end{array}$} & Pagar/ Portal/ Semak & 0.093 & 1.93 & 0.187 \\
\hline & & Penanda Jurusan/ Fakultas/ Universitas & 0.063 & 2.45 & 0.161 \\
\hline & & Trotoar & 0.057 & 2.13 & 0.127 \\
\hline & \multirow{4}{*}{$\begin{array}{l}\text { Access } \\
\text { Control }\end{array}$} & Pintu Masuk Kawasan Perguruan Tinggi & 0.035 & 2.37 & 0.097 \\
\hline & & Pagar/ Portal/ Semak & 0.030 & 1.93 & 0.069 \\
\hline & & CCTV & 0.034 & 1.78 & 0.071 \\
\hline & & Pos Satpam & 0.043 & 1.86 & 0.094 \\
\hline & \multirow[t]{5}{*}{ Maintenance } & Pemeliharaan Penanda & 0.036 & 3 & 0.112 \\
\hline & & Pemeliharaan Fasilitas Keamanan & 0.042 & 2 & 0.086 \\
\hline & & Pemotongan Tumbuhan yang Sudah Lebat & 0.042 & 2 & 0.086 \\
\hline & & Standar Keamanan Pintu Masuk & 0.052 & 2 & 0.106 \\
\hline & & Total & 1 & 39.52 & 2.079 \\
\hline
\end{tabular}

Tabel 8. Pembobotan dan Skoring Penilaian Kualitas Desain Kawasan Unika (Analisis Penyusun, 2018)

\begin{tabular}{|c|c|c|c|c|c|}
\hline \multicolumn{2}{|c|}{ Variabel } & Indikator & $\begin{array}{c}\text { Bobot } \\
\text { (B) }\end{array}$ & $\begin{array}{l}\text { Nilai } \\
(\mathbf{N})\end{array}$ & $\begin{array}{l}\text { Total Skor } \\
(\text { (B x N) }\end{array}$ \\
\hline \multirow{4}{*}{\multicolumn{2}{|c|}{$\begin{array}{l}\text { Karakteristik Aktivitas } \\
\text { Mahasiswa }\end{array}$}} & Waktu Mendatangi Lingkungan Kampus & 0.092 & 2 & 0.184 \\
\hline & & $\begin{array}{l}\text { Intensitas Waktu Mendatangi Lingkungan } \\
\text { Kampus }\end{array}$ & 0.065 & 2 & 0.13 \\
\hline & & Tujuan ke Kampus & 0.074 & 2 & 0.148 \\
\hline & & Moda Transportasi & 0.047 & 2 & 0.094 \\
\hline \multirow[t]{16}{*}{ CPTED } & \multirow{4}{*}{$\begin{array}{c}\text { Natural } \\
\text { Surveillance }\end{array}$} & Pos Satpam & 0.022 & 2.94 & 0.064 \\
\hline & & Lampu Penerangan & 0.045 & 2.16 & 0.097 \\
\hline & & Bangunan yang Mudah Diamati & 0.067 & 2.57 & 0.172 \\
\hline & & Pengaturan Tinggi Pohon dan Semak & 0.059 & 2.36 & 0.139 \\
\hline & \multirow{3}{*}{$\begin{array}{c}\text { Territorial } \\
\text { Reinforcement }\end{array}$} & Pagar/ Portal/ Semak & 0.093 & 2.55 & 0.237 \\
\hline & & Penanda Jurusan/ Fakultas/ Universitas & 0.063 & 2.05 & 0.129 \\
\hline & & Trotoar & 0.057 & 1.98 & 0.112 \\
\hline & \multirow{4}{*}{$\begin{array}{l}\text { Access } \\
\text { Control }\end{array}$} & Pintu Masuk Kawasan Perguruan Tinggi & 0.035 & 2.66 & 0.093 \\
\hline & & Pagar/ Portal/ Semak & 0.030 & 2.55 & 0.076 \\
\hline & & CCTV & 0.034 & 2.17 & 0.073 \\
\hline & & Pos Satpam & 0.043 & 2.94 & 0.126 \\
\hline & \multirow[t]{5}{*}{ Maintenance } & Pemeliharaan Penanda & 0.036 & 3 & 0.108 \\
\hline & & Pemeliharaan Fasilitas Keamanan & 0.042 & 3 & 0.126 \\
\hline & & Pemotongan Tumbuhan yang Sudah Lebat & 0.042 & 2 & 0.084 \\
\hline & & Standar Keamanan Pintu Masuk & 0.052 & 3 & 0.156 \\
\hline & & Total & 1 & 45.93 & 2.378 \\
\hline
\end{tabular}

Total skor didapatkan dari hasil perkalian antara pembobotan dengan nilai masingmasing. Kawasan Undip termasuk dalam kategori cukup dan Unika termasuk dalam kategori baik, dengan total skor pada kawasan Undip sebesar 2,079, sedangkan Unika memiliki total skor sebesar 2,378.Total skor terendah dari penilaian tersebut adalah 1 dan total skor tertinggi dari penilaian tersebut adalah 3. Maka untuk mengetahui penilaian kualitas desain kawasan Undip dan Unika menggunakan pendekatan CPTED berdasarkan persepsi mahasiswa mengacu pada klasifikasi penilaian kualitas desain berikut. 
Tabel 9. Klasifikasi Penilaian Kualitas Desain (Analisis Penyusun, 2018)

\begin{tabular}{ccc}
\hline No. & Total Skor & Keterangan \\
\hline $\mathbf{1}$ & $1-1,67$ & Kurang \\
\hline $\mathbf{2}$ & $1,68-2,35$ & Cukup \\
\hline $\mathbf{3}$ & $2,36-3,03$ & Baik \\
\hline
\end{tabular}

Berdasarkan klasifikasi penilaian kualitas desain dapat diketahui bahwa Undip dalam hal kualitas desain kawasan dengan menggunakan pendekatan CPTED termasuk dalam kategori cukup dengan total skor sebesar 2,079. Sementara itu, untuk kampus Unika pada penilaian kualitas desain kawasan dengan menggunakan pendekatan CPTED termasuk dalam kategori baik dengan total skor sebesar $\mathbf{2 , 3 7 8}$. Pada penilaian tersebut indikator yang memiliki nilai tertinggi yaitu 3 dan nilai terendah adalah 1. Pada karakteristik aktivitas mahasiswa penilaian berdasarkan hasil kuesioner pada kedua perguruan tinggi yaitu waktu mendatangi lingkungan kampus, intensitas waktu mendatangi lingkungan kampus, tujuan mendatangi kampus, dan moda transportasi memiliki skor yang sama pada setiap indikator yaitu sebesar 0,$168 ; 0,113$; 0,117 ; dan 0,081 .

Penerapan CPTED yaitu Natural Surveillance, terdapat perbedaan antara kampus Undip dan Unika. Secara keseluruhan skor pada indikator Natural Surveillance di kampus Unika memiliki skor lebih tinggi dari kampus Undip. Hal tersebut dapat dilihat pada skor pos satpam, lampu penerangan, bangunan yang mudah diamati, dan pengaturan tinggi pohon dan semak di kampus Unika yaitu 0,$066 ; 0,098 ; 0,174$ dan 0,140 . Sementara itu, untuk skor pos satpam, lampu penerangan, bangunan yang mudah diamati, dan pengaturan tinggi pohon dan semak di kampus Undip yaitu 0,042; 0,087; 0,162; dan 0,113.

Territorial Reinforcement dalam penerapan CPTED di kampus Undip cenderung lebih tinggi dari kampus Unika. Hal tersebut dapat dilihat pada skor penanda jurusan/fakultas/universitas dan trotoar di kampus Undip yaitu 0,161 dan 0,127 mendapatkan skor lebih tinggi dari kampus Unika yaitu 0,135 dan 0,118. Sementara itu, pada indikator pagar/portal/semak di kampus Unika memiliki skor yaitu 0,248 dan kampus Undip mendapat skor 0,187. Artinya pada Territorial Reinforcement kampus Undip lebih baik pada penilaian penanda jurusan/fakultas/universitas dan trotoar dari kampus Unika. Namun sebaliknya, kampus Unika memiliki penilaian yang lebih baik dari kampus Undip pada idikator pagar/porta/semak.

Penerapan CPTED berupa Access Control, kampus Unika memiliki penilaian yang lebih baik dari kampus Undip pada seluruh indikator pada Access Control yaitu pintu masuk kawasan perguruan tinggi, pagar/portal/semak, CCTV, dan pos satpam. Skor kampus Unika pada indikator pintu masuk kawasan perguruan tinggi, pagar/portal/semak, CCTV, dan pos satpam yaitu sebesar 0,$109 ; 0,091 ; 0,086$; dan 0,148 , sedangkan pada kampus Undip memiliki skor sebesar 0,097; 0,069; 0,071; dan 0,094.

Selanjutnya, pada penilaian terakhir penerapan CPTED yaitu Maintenance, pemeliharaan penanda dan pemotongan tumbuhan yang sudah lebat di kampus Undip dan Unika memiliki penilaian yang sama dengan skor sebesar 0,112 dan 0,086 dengan kategori baik dan cukup. Pemeliharaan fasilitas keamanan dan standar keamanan pintu masuk di kampus Unika memiliki penilaian yang lebih baik dari kampus Undip. Skor pada pemeliharaan fasilitas keamanan dan standar keamanan pintu masuk di kampus Unika memiliki skor sebesar 0,129 dan 0,159, sedangkan skor kampus Undip sebesar 0,086 dan 0,106.

Pada penilaian tersebut dapat dilihat adanya perbedaan hasil skoring penilaian kualitas desain kawasan kedua perguruan tingggi tersebut menggunakan pendekatan CPTED, hal tersebut dapat terjadi karena adanya perbedaan pada masing-masing perguruan tinggi yang dapat dilihat dari aspek fisik seperti tata guna lahan, kontur, dan kepadatan bangunan serta aspek non fisik seperti luas kawasan, jumlah mahasiswa, dan jumlah aktivitas.

\section{Kesimpulan dan Rekomendasi}

Berdasarkan hasil dari penelitian yang telah dilakukan, dengan melakukan penilaian kualitas desain kawasan Undip dan Unika dengan menggunakan pendekatan CPTED, sasaran pada penelitian ini yaitu menganalisis karakteristik aktivitas mahasiswa, menganalisis kondisi perguruan tinggi menggunakan pendekatan CPTED, penentuan bobot indikator dalam penilaian kualitas desain, serta pembobotan dan skoring penilaian kualitas desain kawasan perguruan 
tinggi, maka pada akhirnya didapatkan penilaian kualitas desain kawasan Undip dan Unika dengan menggunakan pendekatan CPTED yang kemudian dapat ditarik sebuah kesimpulan bahwa terdapat perbedaan nilai pada kedua perguruan tinggi tersebut. Perbedaan nilai pada kedua perguruan tinggi tersebut dapat dipengaruhi oleh beberapa faktor yang dapat dilihat dari aspek fisik dan non fisik kedua perguruan tinggi tersebut. Pada aspek fisik dapat dilihat dari tata guna lahan, kontur dan kepadatan bangunan. Adanya faktor-faktor tersebut menyebabkan permasalahan yang ada pada kedua kawasan tersebut berbeda serta fasilitas yang ada dan kebijakan yang dibuat oleh kampus Undip dan Unika untuk mengurangi kejahatan dan meningkatkan keamanan tentu saja berbeda.

Salah satu keriteria penilaian akreditasi adalah pemenuhan ketersediaan sarana prasarana yang meliputi akses mahasiswa terhadap sarana prasarana, kegunaan atau pemanfaatan sarana prasarana oleh mahasiswa, serta keamanan, keselamatan, kesehatan dan lingkungan dalam menunjang tridharma perguruan tinggi. Dalam hal ini yang lebih ditekankan adalah keamanan dalam menunjang tridharma perguruan tinggi. Meskipun kedua perguruan tinggi tersebut memiliki nilai akreditasi A, namun pada kondisi ekstiting masih belum menjamin keamanan bagi setiap mahasiswa karena masih sering terjadi tindak kejahatan. Belum terjaminnya keamanan bagi setiap mahasiswa disebabkan oleh perilaku dan adanya kesempatan dari pelaku kejahatan. Perilaku tersebut dipengaruhi dua faktor yaitu adanya niatan melakukan kejahatan yang mendorong pelaku serta kejahatan yang dilakukan pelaku tanpa ada paksaan dari orang lain. Akan tetapi kesempatan terjadi ketika pelaku memiliki peluang besar dalam melakukan tindak kejahatan dan resiko tertangkap tangan ketika melakukan kejahatan kecil. Selama masih terdapat perilaku dan kesempatan dari pelaku kejahatan, maka kejahatan di perguruan tinggi akan tetap terjadi meskipun memiliki sarana dan prasarana keamanan yang memadai.

Berdasarkan hasil penelitian yang telah dilakukan, maka dapat dirumuskan rekomendasi yang dapat diberikan berupa saran bagi pengelola Undip dan Unika. Saran tersebut dapat dijadikan sebagai acuan untuk meningkatkan keamanan di kawasan Undip dan Unika. Rekomendasi tersebut diajukan kepada pihak pengelola kampus, adapun rekomendasi yang dapat diberikan adalah sebagai berikut:

\section{Kampus Universitas Diponegoro (Undip)}

a. Memperbaiki penerangan jalan yang rusak atau redup dan menambah jumlah lampu penerangan jalan pada bagian yang belum terdapat lampu penerangan jalan, seperti pada jalan penghubung Undip dengan Jl. Baskoro dan Undip dengan Jl. Jurang Blimbing.

b. Menambahkan pagar/semak pada kawasan yang belum terdefinisi batas kepemilikannya, seperti pada Gedung Kuliah Bersama Fakultas Teknik yang tidak memiliki pembatas.

c. Pemasangan CCTV pada bagian dalam bangunan dan tempat parkir diseluruh departemen di Undip, jadi tidak hanya berada pada pintu masuk saja.

d. Mengatur akses jalan tembus kawasan Undip dengan membatasi akses melalui jalan tembus tersebut dan untuk akses utama kampus melewati jalur-jalur utama saja. Namun juga tetap memerhatikan akses terhadap Rumah Sakit Nasional Diponegoro (RSND).

e. Pemberian sanksi tegas kepada mahasiswa yang melakukan kegiatan kampus melebihi jam malam tanpa izin yang jelas.

f. Adanya pemotongan tumbuhan yang sudah lebat secara rutin di seluruh kawasan Undip sehingga tidak menghalangi pandangan dari dalam maupun luar kampus.

\section{Kampus Universitas Katolik Soegijapranata (Undip)}

a. Memperbaiki penerangan jalan yang rusak atau redup dan menambah jumlah lampu penerangan jalan pada bagian yang belum terdapat lampu penerangan jalan, seperti pada jalan menuju pintu keluar kampus.

b. Pemberian penanda pada seluruh bangunan sebaiknya menggunakan nama jurusan dan fakultas, tidak hanya nama Gedung saja sehingga batas kepemilikannya dapat terdefinisi dengan jelas.

c. Adanya pemotongan tumbuhan yang sudah lebat secara rutin di seluruh kawasan Undip sehingga tidak menghalangi pandangan dari dalam maupun luar kampus

d. Pemberian sanksi tegas kepada mahasiswa yang melakukan kegiatan kampus melebihi jam malam tanpa izin yang jelas. 


\section{Referensi}

BPS Kota Semarang. (2016). Kota Semarang dalam Angka 2016.

Clarke, R. V. (2009). The Theory of Crime Prevention Through Environmental Design. Police Management Studies Quarterly, 1-20. Retrieved from https://pdfs.semanticscholar.org/4a94/e72074e829aba49ff001e177870d37be13d5.pdf

Danville Police. (2012). Crime Prevention Through Environmental Design ( CPTED ) A Design and Security Handbook Table of Contents.

Effendi, S., \& Tukiran. (2014). Metode Penelitian Survei. Jakarta: LP3S.

Glaeser, E. L., \& Sacerdote, B. (1999). Why is There More Crime in Cities? Journal of Political Economy, 107(S6), S225-S258. https://doi.org/10.1086/250109

Nazir, M. (1983). Metode Penelitian. Jakarta: Ghalia Indonesia.

Pauls, T., Zywna, D., Prochilo, K., White, S., Christie, F., \& Hainer, C. (2000). Crime Prevention Through Environmental Design : General Guidelines for Designing Safer Communities. Prevention.

Peeters, M. P., \& Vander Beken, T. (2017). The relation of CPTED characteristics to the risk of residential burglary in and outside the city center of Ghent. Applied Geography, 86, 2017. https://doi.org/10.1016/j.apgeog.2017.06.012

Prasetyo, B., \& Jannah, L. M. (2005). Metode Penelitian Kuantitatif: Teori dan Aplikasi. Jakarta: Raja Grafindo Persada.

Rizkyawan, R. (2012). Persepsi Mayarakat terhadap Koridor Ruang Kota Jalan Pahlawan Semarang. Universitas Diponegoro.

Singapore National Crime Prevention Council. (2003). Crime Prevention through Environmental Design; Guide Book. Prevention, 68.

Sohn, D. W. (2016). Residential crimes and neighbourhood built environment: Assessing the effectiveness of crime prevention through environmental design (CPTED). Cities, 52, 86-93. https://doi.org/10.1016/j.cities.2015.11.023

Supandi. (2015). Pengertian mengenai Kejahatan, Penjahat dan Premanisme. Repository Unisba, 11-42.

Wizaka, W. (2012). Adaptasi Crime Prevention Through Environment Design (CPTED): Studi Kasus Fenomenas Desain Fasilitas Publik Konsep Crime Prevention Through Environmental Design (CPTED) dan Sejarahnya, 51-58.

Zahm, D. (2007). Using Crime Prevention Through Environmental Design in Problem-Solving by.

Zen, I., Amalina, N., \& Mohamad, A. (2014). Adaptation of Defensible Space Theory for the Enhancement of Kindergarten Landscape. Procedia - Social and Behavioral Sciences, 153, 23-35. https://doi.org/10.1016/j.sbspro.2014.10.037 